Fine Monica, Gironda John, Petrescu Maria

\title{
Prosumer Motivations for Electronic Word-of-Mouth Communication Behaviors
}

\begin{abstract}
Purpose

"Prosumers" (combining "producer” and “consumers”) describes consumers' ability to openly share their product/service experiences and thereby drive sales and digital marketing. Understanding what motivates active prosumers to engage in electronic word-of-mouth (eWOM) and share or review their hotel experiences online can help organizations empathize with consumers and utilize their messages to co-create value. Identifying prosumers' motivators can enable companies to properly target them as resources for review or consumer feedback studies. This study investigated the influence of motivators (intrinsic and extrinsic), service quality, and age on consumers' electronic word-of-mouth communication behaviors.
\end{abstract}

\section{Design/methodology/approach}

A panel of 204 travelers was surveyed regarding their hotel travel experiences, propensity to write online reviews, preferred review-writing platform, motivations for writing reviews, and impressions of service quality. To test the hypotheses, a multivariate regression analysis was performed with eWOM as the dependent variable. Differences in eWOM as a function of preferred review platform were also tested using ANOVA, with a multiple comparison analysis that underlines the differences between prosumers who prefer different types of review platforms and their eWOM behaviors.

\section{Findings}

Both intrinsic and extrinsic motivators, as well as service reliability, had a significant influence on eWOM behavior, while service tangibility had a negative relationship. Additionally, prosumers' engagement in eWOM about their hospitality experience differed according to their preferred review platform.

\section{Originality/value}

This paper develops a better understanding of what motivates people to engage in the eWOM communication behavior of writing online hotel reviews, by showing the effect of consumer motivations and service quality variables on prosumers' engagement in online review behavior.

Keywords: Electronic Word-of-Mouth, eWOM, Online Reviews, Prosumers, Service Quality, SERVQUAL

Paper type: Research paper 


\section{Introduction}

Found to be the principal reason for $20-50 \%$ of all buying decisions, electronic word-ofmouth (eWOM) continues to be a force in digital marketing, representing a valuable and powerful information source for consumers (Bughin et al., 2010). Consumers ranked eWOM as the most influential factor in their relationships with brands, as well as a top source of trustworthy information (Bulbul et al., 2014; Nielson, 2013). In the tourism and hospitality industry, online hotel reviews are one of the most important forms of eWOM. Eighty-one percent of consumers find online user reviews to be an important information source when choosing between hotels, while 49\% add that they would not book a hotel without reviews (Boykin, 2015). Online reviews are seen as highly credible, with $88 \%$ of travelers trusting them as much as personal recommendations from friends or family members (Anderson, 2014).

With the rise of eWOM has come the concept of the "prosumer," which describes how consumers have become much more influential due to their ability to openly, quickly, and easily share their product/service experiences with a large number of people (Gunelius, 2010). Much of the content on social networking sites such as Facebook, Twitter, and Instagram, as well as review platforms including TripAdvisor, Google Reviews, and Yelp, comes from user postings, making these users co-creators or producer-consumers (i.e. prosumers). Through co-creation of content and sharing of experiences, prosumers have become an integral part of the brandimaging process for marketers (Siuda and Troszynski, 2016). Review platforms and social communities have afforded the easy sharing and discovery of information for prosumers. The same individual may act as a prosumer in the morning, posting reviews about their own experiences, and at night become a consumer, as they read others' reviews to choose a restaurant, hotel, or other service. Since purchasing decisions are seen as high risk in the hotel industry, reference group evaluation is crucial in the decision-making process (Litvin, 2007); this further

$$
1
$$

(c) Emerald Publishing Limited

This is a pre-print of a paper and is subject to change before publication. This pre-print is made available with the understanding that it will not be reproduced or stored in a retrieval system without the permission of Emerald Publishing Limited. 
heightens the impact of prosumers sharing eWOM.

Prosumers’ powerful influence underscores the tremendous significance for businesses, particularly in the hospitality and tourism industry, to entice users to write online reviews. A better understanding of what motivates active prosumers to share or review their hotel experiences through eWOM will help organizations empathize with consumers and utilize their messages for co-creating value. Furthermore, by identifying reviewers' motivators, businesses can properly target them as resources for review or consumer feedback studies.

So far, there are few studies regarding the motivations of eWOM review-writing behaviors (Cantallops, 2014). This study seeks to understand what motivates people to engage in the eWOM communication behavior of writing hotel reviews online. Aiming to fill the gap between studies about the importance of eWOM online reviews and those involving the identification of review-writer characteristics, this study specifically identifies the motivators and character traits of reviewers who are most likely to post online. Existing studies examine motivations for positing reviews, including motivations based on review platform, motivations based on personality, and motivations based on positive or negative tone of review. This study investigates both intrinsic and extrinsic motivations to see if either affects consumers' likelihood to post reviews. Aside from motivators, this study also explores the effects of service quality and age in order to determine if either impacts review-writing eWOM behavior. Finally, this study attempts to identify the online communities and review-writing platforms on which prosumers tend to most frequently write reviews.

Identifying these motivators and characteristics of online reviewers will help hoteliers understand which segments of consumers are likely to post reviews after their stay. Identifying prosumers service quality perspectives will also help hoteliers understand customers’ 
expectations for the experience of a hotel stay and where hotels may currently be lacking. Once hotel managers better understand who is most likely to review and why, they can refine reviewgenerating initiatives and ensure their properties meet the interests of positively-motivated reviewers. In addition, examining service quality will help provide insight into how a customer's hotel experience influences their eWOM review-writing behavior. Furthermore, testing eWOM review-writing motivators and preferred review-writing platforms will aid our understanding of reviewers’ most influential motivators. Key research questions include:

- Do certain motivational factors influence likelihood of reviewing more than others?

- Does perceived service quality affect likelihood to write a review?

- Do online review platform preferences affect engagement in eWOM?

- Does age affect online eWOM review behavior?

\section{Literature Review}

\subsection{Electronic Word-of-Mouth and Consumer Online Reviews}

Traditional word-of-mouth communication about a particular product or service describes the exchange of conversation between people (Jalivand, 2010). Word-of-mouth communication undoubtedly influences consumer purchase and decision behavior: a friendly conversation about products and service can attract or deter the recipient from using the same business. Reviews and word-of-mouth communication are not a new concept for hotel managers. However, the explosion of eWOM communication and its influence on purchase behavior has prompted managers to focus more of their attention on reputation management and review-generating initiatives. Typically, word-of-mouth exchange takes place on a conversational, person-to-person basis. Yet, the accessibility and capability of the Internet and online communities have completely flipped this concept on its head, and electronic word-of-mouth communication has 
become increasingly important. eWOM is defined as any review, be it informative or recommending, that a consumer posts (online) about a product or service they have experienced, making it available to an abundance of current and/or potential consumers (Jalivand, 2010). Researchers and marketing practitioners have noted that approximately 25 percent of consumer comments are critical or negative, demonstrating that electronic word-of-mouth can bring disadvantages as well as benefits (Plummer et al. 2007).

While positive word-of-mouth can significantly and positively impact consumer decision making and purchasing decisions, research has shown that negative word-of-mouth can have an even greater influence and impact consumer attitude and behavior (Herr et al., 1991).

Dissatisfied customers tend to be more aggressive in their communication, seeking to tell more people about their experience than those who are satisfied with their purchases. Consumers who take into consideration brand and product information from other consumers could be more inclined to pay attention to negative reviews and comments than positive ones (Breazeale, 2009).

Traditional marketing knowledge notes that consumer complaints and negative messages are important. Research has shown that, when consumers complain, it indicates they have a relationship with the brand and care about the specific situation. Any communication from consumers, including negative messages, represents a way for the company to receive feedback and ideas about what needs to be improved and changed about its products, services, and operations. Customer complaints are a source of knowledge and intelligence for any company that knows how to manage them (Blazevic and Lievens, 2008).

Because of the widespread use of the Internet, consumers can easily express their feelings online; although some consumer-generated content, including reviews and social media posts, is positive, significant negative online content can affect a brand's image. Researchers have noted 
that certain types of negativity may be more important for companies to professionally manage because they are more likely to be shared, especially in a social media context. Customers who experience anxiety or anger are more likely to transmit those experiences to others than feelings of sadness or disappointment, making it more important for marketers to try to resolve those anxious and angry experiences (Berger and Milkman, 2012).

Several papers have been published and extensively reviewed that identify the significance and importance of electronic word-of-mouth marketing for business success (Cantallops, 2014; Crotts et al., 2009; Pietro et al., 2012). Nearly 90\% of consumers making new product purchase decisions mentioned eWOM such as online reviews, blogs, or other usergenerated content (UGC) (Cheung and Dimple 2012) as their preferred form of communication. In the context of hotels, this relationship could be even stronger (King, Racherla, and Bush 2014). Studies vary from tracing gender effects of eWOM communication (Memarzadeh et al., 2015; Sun and Qu, 2011), examining satisfaction (Barreda and Bilgihan, 2013; Loureiro and Kastenholz, 2011), to analyzing service failures (Sánchez-García and Currás-Pérez, 2011; Swanson and Hsu, 2009). However, little research has investigated consumer motivators for eWOM review-writing behaviors (Cantallops, 2014).

Some researchers have explored eWOM review-writing participation and its impact on consumer loyalty (Chen, 2012), while others have studied eWOM review frequency on Facebook as it relates to personality and tone of message (Yoo et al., 2013). Researchers evaluated consumer motivation to produce eWOM content by surveying a TripAdvisor travel panel of roughly 1,200 respondents (Yoo and Gretzel, 2008). The survey was developed in an effort to identify motives for online review writing and evaluate demographic differences in these motives. Researchers argue eWOM communication does not comprise an exchange of 
conversation, like traditional WOM; instead, eWOM involves an anonymous post without expectation of conversation in return. The study analyzed as motivators: enjoyment, power, venting negative feelings, concern for other consumers, helping the company, expressing positive feelings, and self-enhancement (Yoo and Gretzel, 2008).

Word-of-mouth exchange undeniably influences consumer purchase decisions, as consumers typically reach out to friends or family whose opinions they trust. Once online content creation became popular, researchers began to study perception of trust online and offline (Glen, Cinda, Antonio, 2009). As Glen describes, "In the traditional [offline] sense, trust often connotes credibility, integrity, reliability, confidence and benevolence” (Glen, 2009, pg. 180); studies revealed the same characteristics were associated with trust online. (Glen, 2009). Many studies found consumers' deem online reviews to be more trustworthy than advertisements geared to the mass market (Cheung and Dimple 2012). Now that reading online reviews has become an integral part of the consumer purchase journey, especially for high-risk purchases like flights, destinations, and hotel stays, studies have investigated specific cues in online content that establish consumer trust, such as connection to poster, reviewer rating, and positive or negative reviews (Pan , Chiou, 2011). Identifying consumers general level of trust in reviews can provide a better understanding about whether or not it affects how frequently consumers write reviews; however, trust was dropped from this study because of issues with self-reported behaviors.

Several studies have used researched performed by Hennig-Thurau as a foundation for extended eWOM research. Rooted in the Web 2.0 switch from consumers to prosumers, one such study investigated "the influence of seven motivations on the involvement to write positive and negative online reviews and how personality plays a role” (Rensink, 2013, p. 3). Rensink (2013) drew the seven motivational factors from Hennig-Thurau (2004), adding factors 
motivating positive and negative traditional word-of-mouth communication. The final list of motivations was: self-enhancement, social benefits, advice seeking, concern for other consumers positive, concern for other consumers negative, venting negative feelings, and helping the company. Rensink (2013) also discussed the relation of the five-factor personality model to eWOM exchange, aiming to explore whether or not personality type affects involvement for each motivational factor. Hypotheses were developed for extraversion, agreeableness, conscientiousness, neuroticism, and openness. The research model used involvement as the dependent variable, with the seven motivating factors, personality traits, and tone of content as independent variables. For positive and negative reviews, social benefit motivation and review involvement were positively correlated. The hypothesis that "more neurotic individuals are more involved in writing reviews to vent negative feelings than less neurotic individuals” (Rensink, 2013, p. 24) was the only personality hypothesis supported by data. Whereas the study cited above uses involvement as its dependent variable, this study examines motivations for online review-writing behavior.

\section{Hypotheses Development}

\subsection{Consumer Motivations}

Consumer motivations to write and post eWOM reviews are important for hotel managers to understand, since knowledge of common motivations could help managers recognize and rectify a situation that might motivate a negative consumer review. Motivations can be broken down into intrinsic and extrinsic motives (Deci, 1975). Intrinsically, the consumer feels motivation because they have a need to understand out of curiosity, accomplishment, achievement, self-development, and want to stimulate specific sensations (Blais, Briere, Fortier, Pelletier, Tuson \& Vallerand 1995). These elements also explain having an internal locus of 
control. Extrinsically, the consumer experiences motivation for reasons other than their own sake, such as desire to regulate praise and awards, belonging, or perhaps they feel motivated to share so they can achieve personal goals (Blais, et al., 1995). These are attributed to outside factors, exhibiting an external locus of control. Both intrinsic and extrinsic motives have been found to have a significant impact on behavioral intention (Davis et al., 1992), including that of eWOM (Yoo et al., 2013). Examining both intrinsic and extrinsic motivations provides a clearer picture of the types of motives that drive prosumers to post a review online. Because there may be both internal feelings of well-being as well as possible external rewards for posting a review, we anticipate that both intrinsic and extrinsic motives will positively impact review behavior. Therefore, the following hypotheses are proposed:

H1: Intrinsic motivators have a positive relationship with online eWOM review behavior engagement.

H2: Extrinsic motivators have a positive relationship with online eWOM review behavior engagement.

\subsection{Service Quality}

Widely accepted as an accurate measure of perceived service quality, SERVQUAL "is a concise multiple-item scale with good reliability and validity that retailers can use to better understand service expectations and perceptions of consumers and, as a result, improve service” (Parasuraman and Zeithhaml, 1988, p. 14). SERVQUAL measures five dimensions of servicequality (tangibles, reliability, responsiveness, assurance, and empathy), in order to evaluate consumers' satisfaction with a particular type of service and their perception of quality for a particular company within that service category (Parasuraman and Zeithhaml, 1988).

The tangibles dimension refers to the physical facilities, equipment, and appearance of personnel involved in the provision of services. Reliability refers to the ability to dependably and 
accurately perform the promised service. Responsiveness deals with the willingness to help customers and provide prompt service. Assurance is related to the knowledge and courtesy of employees involved in the service and their ability to inspire trust and confidence. Empathy refers to the caring, individualized attention the firm provides to its customers.

Service quality has been found to impact a number of consumer outcomes, including purchase intentions, customer loyalty, complaints, price sensitivity, and word-of-mouth (Alexandris et al., 2002; Harrison-Walker, 2001; Zeithaml et al., 1996; Fine, Clark, and Scheuer, 2016). In addition, Jeong and Jang (2011) investigated service quality’s impact on eWOM, finding that a good experience positively influences favorable eWOM. While those results are important, that study utilized service quality as a unidimensional construct. Therefore, a study examining how each of the five dimensions of SERVQUAL impacts eWOM behavior is still needed. This study makes use of SERVQUAL to uncover how each dimension of service quality might affect online review-writing behavior, in order to determine whether some dimensions of service quality are more impactful than others in influencing consumers to write online eWOM reviews. Looking at the dimensions of service quality from the context of online eWOM reviews, we estimate that the higher the level of each dimension of service quality, the more likely prosumers will be to engage in writing online reviews about their hospitality experience.

Therefore, the following hypotheses are proposed:

H3: The level of service tangibles has a positive relationship with online eWOM review behavior engagement.

H4: The level of service reliability has a positive relationship with online eWOM review behavior engagement.

H5: The level of service responsiveness has a positive relationship with online eWOM review behavior engagement.

H6: The level of service assurance has a positive relationship with online eWOM review 
behavior engagement.

H7: The level of service empathy has a negative relationship with online eWOM review behavior engagement.

\subsection{Preferred Review-Writing Platform}

Little research has investigated eWOM review-writing behavior with regard to preferred review-writing platform. Different motivators have been shown to influence frequency of platform visits and comment writing (Hennig-Thurau et al., 2004), but there is little research to prove a correlation between eWOM review-writing behavior and preferred review-writing platform. Yen and Tang (2015) explored eWOM motivators and platform preference between Facebook and Tripadvisor. Findings revealed that extraversion, social benefits, and dissonance reduction were correlated with Facebook, while altruism and platform assistance were correlated with Tripadvisor (Yen and Tang, 2015). Given these findings, we also investigate platform preference, aiming to uncover if it has an impact on eWOM review-writing behavior. Along with Facebook and TripAdvisor, this study also includes Google Reviews and Yelp as additional review-writing platform options. Thus, we hypothesize:

H8: Differences in online eWOM review behavior occur as a function of the review platform preferred.

\subsection{Age}

It would also be useful for hoteliers to know whether age has any effect on eWOM review behavior, as this would assist in their market targeting decision-making efforts. In terms of previous studies, advertising research found that younger individuals evaluate commercials in a more positive way than older consumers (de Gregorio and Sung, 2010). Research also noted that younger consumers are more likely to be heavy Internet users when compared to older individuals (Korgaonkar and Wolin, 1999). Market maven studies noted that the younger 
population is also more likely to engage in consumption discussions and maven activities (Feick and Price, 1987; Laughlin and MacDonald, 2010). In the viral advertising context, studies have shown that the main target and market for viral ads is again the younger generation (Dobele et al., 2007). Therefore, we hypothesize that age is negatively related to consumers’ propensity to engage in online eWOM reviewing activities.

H9: Age has a negative relationship with online eWOM review behavior engagement.

\section{Methodology}

This study used selective purposive sampling in order to obtain a sample of respondents who were known travelers, as that would be ideal for a hotel review study. A survey panel of 2,350 known travelers across the US was donated for purposes of this study by a marketing/advertising agency in the south-east. An initial invitation to the survey was delivered via Survey Monkey email, and a reminder was sent three days later to anyone who had not already responded to the survey. The survey respondents were then filtered to include respondents who had written online travel reviews in the past. This reduced the final sample to a total number of 204 respondents.

The sample was heterogeneous in terms of respondents' demographic characteristics. The survey participants were all US residents over the age of 18 who reported residency across 34 states, with South Carolina (18\%) and California (7\%) holding the majority. They ranged in age from 25-75 years old, with 45-54 year olds accounting for 23\%. All participants reported having completed high school, with a bachelor's degree being the most common level of education (29\%). Total household income was distributed among participants, with $19 \%$ in the $\$ 35-\$ 49.9 \mathrm{~K}$ range, $23 \%$ in the $\$ 50-\$ 74.9$ range, and $17 \%$ in both $\$ 75-\$ 99.9 \mathrm{~K}$ and $\$ 100-\$ 149.9 \mathrm{~K}$ ranges.

The survey panel used was a group of known travelers and the survey instrument 
confirmed travel behavior, as $97 \%$ of travelers reported having taken one to nine or more trips in the last 12 months. The final sample of 204 respondents included only consumers who travelled on one to nine or more trips in the last 12 months. The majority of participants reported shorter trip lengths: 54\% reported trips lasting one to two nights, and 30\% reported three to four night trips. When asked to report their purpose of travel, participants rated leisure travel highest, followed by family visits and business. Descriptive statistics and correlations are reported in Tables 1.

\section{(Please insert Table 1 about here)}

\subsection{Measures}

eWOM. Consumer-reported eWOM review-writing behaviors serves as the dependent variable of study. eWOM review-writing behavior was measured by adapting multiple choice items from Yen and Tang (2015) and from Alhidari (2015). The items are seen in Table 2, with great factor loadings in factor analysis and with very high Cronbach’s alphas, showing good reliability for the scale.

\section{(Please insert Table 2 about here)}

Service Quality. Two survey items per dimension were used for this study in an effort to reduce participants’ response burden. Participants were asked about their perceptions of service quality for their typical hotel stay experience, with response options ranging from 1 (strongly disagree) to 7 (strongly agree), as shown in Table 2.

Motivators. Extrinsic and intrinsic motivators were measured based on items adapted from Yoo and Gretzel (2008) and Hennig-Thurau et al. (2004), as shown in Table 2. All motivator items had response options ranging from 1 (strongly disagree) to 7 (strongly agree) following the question prompt: "Please answer the following based on the pretext 'I write hotel reviews on virtual platforms because..."” Deductive reasoning and exploratory factor analysis 
was used to further group motivators into intrinsic and extrinsic motivator categories.

Preferred Review Platform. Yen and Tang's (2015) study was the frame of reference for choosing the platforms Tripadvisor and Facebook. In addition, Google was chosen as a platform because "Google now processes... 3.5 billion searches per day and 1.2 trillion searches per year" (Google Search Statistics 2012). Yelp was chosen because Apple’s IOS software holds a 35\% market share in the mobile operating systems (OS) market, and Yelp reviews are now featured in the Apple map application on IOS devices (Operating System Market Share 2015). Preferred review-writing platform was measured by asking prosumers to "Please select your preferred review-writing platform” with response options for each platform. Age response options ranged from 1 (under 21) to 9 (75+ years).

\subsection{Data Analysis}

To test our hypotheses, we first performed a multiple regression analysis with review behavior as the dependent variable, by using the regression factor scores for each variable of interest.

We also tested the differences in review behavior as a function of the preferred review platform by using an ANOVA test. We include a multiple comparison analysis using the LSD method, which underlines the differences between prosumers who prefer different types of review platforms and their review behaviors.

\section{Results and Discussions}

The results of the multivariate regression analysis showed a value of 0.373 for adjusted R-square, which underlines the fact that the variables in the model provide a good explanation for consumers' review behavior. Both intrinsic and extrinsic motivators had a significant influence on review behavior, providing support for hypotheses 1 and 2 . This confirms previous 
literature showing that intrinsic and extrinsic motives have a significant impact on eWOM (Yoo et al., 2013), and affirms that they are important factors in the context of online reviews. As Table 3 shows, the overall regression model is significant and has a well-adjusted R-square value of 0.373 .

\section{(Please insert Table 3 about here)}

Regarding the five SERVQUAL dimensions, the regression analysis found two of them, service tangibility and reliability, as significantly important for consumers’ online eWOM review behavior. Service tangibles had a significant relationship with consumers’ engagement in online eWOM review behavior. However, the relationship was a negative one: as consumers were more dissatisfied, they were more likely to engage in online eWOM review-writing behavior. Thus, hypothesis H3 was not supported. This could be due to the fact that negative service experiences have been shown to have a greater impact on WOM behaviors, in that consumers are more likely to tell others about a negative experience than a positive one (Söderlund, 1998). They may post reviews as a form of revenge when companies disappoint them and do not act according to standards (Perkins 2009). When consumers tell others about their positive experiences, they tell fewer people than they do when they have a negative experience (Söderlund, 1998). Thus, it would appear that as consumers are more dissatisfied with tangible aspects, they are more likely to engage in online review-writing behavior.

Reliability appears to have been the main factor positively related to engagement in eWOM review-writing behavior: when they found a service highly reliable, prosumers were more likely to engage in spreading positive word-of-mouth about it. Therefore, hypothesis H4 was supported. However, the other SERVQUAL dimensions of responsiveness, assurance and empathy were not significant, and thus hypotheses H5, H6, and H7 were not supported. This 
could have been due to an overwhelming importance of tangibles and reliability in the case of hospitality services, which leads to negative and positive word-of-mouth. As expected, age was found to have a negative relationship with engagement in eWOM review-writing, which affirms that younger consumers are more likely to participate in this type of eWOM.

\section{(Please insert Table 4 about here)}

Regarding the ANOVA results presented in Table 4, the analysis showed that consumers' engagement in online word-of-mouth about their hospitality experience differed as a function of their preferred review platform $[\mathrm{F}(\mathrm{df} 1, \mathrm{df} 2)=7.33, \mathrm{p}<.001]$. The multiple comparison analysis showed that there were significant differences in engagement in online reviews between consumers who listed their favorite review platforms as either Facebook, Google, or TripAdvisor, and those who did not favor one over the others. However, there was no significant difference in eWOM behavior between consumers that listed Yelp as their favorite review platform and those who did not have a preferred review platform. Therefore, hypothesis H8 was partially supported. As seen in the result tables, both the multiple regression and the ANOVA model are significant. Table 5 summarizes each of the hypotheses and the results.

\section{(Please insert Table 5 about here)}

\section{Conclusions}

The main contributions of this study show the effect of consumer motivations and service quality variables on prosumers' engagement in online eWOM review behavior. The study underlines the positive effect of both intrinsic and extrinsic motivations on engagement in eWOM review behavior. Results have also shown the effect of two dimensions of service quality, those of tangibles and reliability, on engagement in eWOM review-writing behavior, 
which provides a theoretical contribution to service research and the base for future studies on this topic. The analysis also confirmed the importance of age and review platform preferences, offering useful starting points for marketing managers who want to improve their online reputation management strategies. Overall, the results show the importance of prosumer motivations, perceptions about service quality, and age as main influencers on engagement in online eWOM review-writing behavior, which represents a useful advancement for marketing and hospitality research and practice. The in-depth implications of each model and the support provided for the hypotheses we formulated are discussed in the next section.

\section{Implications}

The findings of the analysis underline the importance of consumer motivations and service quality in the context of eWOM review behavior. For marketing and hospitality research, this shows the benefits of including not only individual characteristics and demographics when analyzing eWOM review behavior, but also elements such as perceptions of service quality. Given the differences in how the dimensions of service quality affect consumers' engagement in online eWOM review behavior, this represents a very important topic for research and can be included in future studies that analyze the prosumer review behavior model.

Regarding the implications for practitioners, this study highlights the important role played by service quality in the hospitality industry and its effect on their involvement in online eWOM reviews. Managers should constantly focus on offering great service to their guests, while at the same time motivating them to engage in posting positive eWOM reviews about their trip experience. Moreover, as the results of this study imply that various dimensions of service quality have a different impact, managers should especially focus on the aspects that consumers 
consider important and consistently include in their reviews, such as the tangibles dimension. The results of this study also have the potential to provide to businesses more information to improve the social aspects of vacationing, which can not only improve perceptions about service quality, but can also have a positive influence on consumers’ motivations.

\section{Limitations and suggestions for future studies}

The limitations of this study were primarily related to the sample size and characteristics. While the sample was heterogeneous in terms of demographic characteristics and able to obtain responses from residence across 34 states, the sample still could have been broader and larger. Therefore, future studies could attempt to acquire a larger sample size as well as collect responses from residence of all 50 states. The survey was open for two weeks, but an extended “open-survey” for a longer period of time could have produced more responses. In addition, surveying a panel of known frequent reviewers, such as a TripAdvisor panel, would also be a great way to improve the survey sample in terms of increasing the sample size and collecting responses from residence of additional states. Future studies following this survey could include a qualitative analysis of eWOM review behavior and its impact on consumer trust, as this would provide a richer and deeper investigation into not only what variables affect eWOM, but also how eWOM specifically affects other areas that impact consumers' decision-making. Finally, future studies should focus on the importance of each dimension of service quality, as well as consumers' reactions and likelihood to posts eWOM reviews in cases of high perceived satisfaction or dissatisfaction with the service. Extending each of the constructs to more accurately measure SERVQUAL would take more time, but may reveal significant results among constructs. 


\section{REFERENCES}

Alexandris, K., Dimitriadis, N., and Markata, D. (2002), “Can perceptions of service quality predict behavioral intentions? An exploratory study in the hotel sector in Greece”, Managing Service Quality: An International Journal, 12 (4), pp. 224-231.

Alhidari, A., Iyer, P., and Paswan, A. (2015), "Personal level antecedents of eWOM and purchase intention, on social networking sites”, Journal of Customer Behaviour, 14 (2), pp. 107125.

Anderson, M. (2014), “88\% Of Consumers Trust Online Reviews As Much As Personal Recommendations”, BrightLocal, from http://searchengineland.com/88-consumers-trust-onlinereviews-much-personal-recommendations-195803.

Barreda, A., and Bilgihan, A. (2013), “An analysis of user-generated content for hotel experiences”, Journal of Hospitality and Tourism Technology, 4(3), pp. 263-280.

Blais, M., Briere, N., Fortier, M., Pelletier, L., Tuson, K., Vallerand, R. (1995.) Toward a New Measure of Intrinsic Motivation, Extrinsic Motivation, and Amotivation in Sports: The Sport Motivation Scale. Journal of Sport and Exercise Psychology. (p. 35-53).

Blazevic, V., and Lievens, A. (2008), “Managing innovation through customer coproduced knowledge in electronic services: An exploratory study”, Journal of the Academy of Marketing Science, 36 (1), pp. 138-151.

Breazeale, M. (2009), “An Assessment of Electronic Word-of-Mouth Research,” International Journal of Market Research, 51(3), pp. 297-318.

Boykin, J. (2015), “Start Monitoring Your Online Reviews Now: No Excuse for Ignoring Online Reputation”, Internet Marketing Ninjas, from < http://www.internetmarketingninjas.com/ 
blog/marketing/start-monitoring-your-online-reviews-now-no-excuse-for-ignoring-onlinereputation-jimandann/>.

Bughin, J., Doogan, J., and Vetvik, O.J. (2010), “A new way to measure word-of-mouth marketing”, McKinsey Quarterly, from < http://www.mckinsey.com/businessfunctions/marketing-and-sales/our-insights/a-new-way-to-measure-word-of-mouth-marketing>.

Bulbul, C., Gross, N., Shin, S., and Katz, J. (2014), "When the Path to Purchase Becomes the Path to Purpose”, Think with Google, http://think.storage.googleapis.com/docs/the-path-topurpose_articles.pdf.

Cantallops, A. S., and Salvi, F. (2014), "New consumer behavior: A review of research on eWOM and hotels. International Journal of Hospitality Management”, 36, pp. 41-51. doi:10.1016/j.ijhm.2013.08.007.

Chen, C.-Y., Chen, T.-H., Chen, Y.-H., and Yu, S.-E. (2012), “The spatio-temporal distribution of different types of messages and personality traits affecting the eWOM of Facebook. Natural Hazards”, 65(3), pp. 2077-2103. doi:10.1007/s11069-012-0468-y.

Cheung, Christy and Thadani Dimple (2012). "The impact of electronic word-of-mouth communication: A literature analysis and integrative model.” Decision Support Systems 54 (2012) 461-470.

Crotts, J. C., Mason, P. R., and Davis, B. (2009), “Measuring guest satisfaction and competitive position in the hospitality and tourism industry an application of stance-shift analysis to travel blog narratives”, Journal of Travel Research, 48(2), pp. 139-151.

Davis, F. D., Bagozzi, R. P., and Warshaw, P. R. (1992), “Extrinsic and intrinsic motivation to use computers in the workplace”. Journal of Applied Social Psychology, 22 (14), pp. 1111-1132. 
Deci, E. L. (1975), Intrinsic motivation plenum. New York.

de Gregorio, F. and Y. Sung (2010), “Understanding Attitudes toward and Behaviors in

Response to Product Placement: A Consumer Socialization Framework,” Journal of Advertising, 39 (1), pp. 83-96.

Digman, J. M. (1990), “Personality Structure: Emergence of the Five Factor Model”, Annual Review of Psychology, 41, pp. 417-440.

Dobele, A., Lindgreen, A., Beverland, M., Vanhamme, J. and R. van Wijk (2007), "Why Pass on Viral Messages? Because They Connect Emotionally,” Business Horizons, 50, pp. 291304.

Feick, L.F. and L.L. Price (1987), “The Market Maven: A Diffuser of Marketplace Information,” Journal of Marketing, 51, pp. 83-97.

Fine, M., M. Clark and C. Scheuer (2016), "Value-Added University Services: The Importance of On-Campus Recreational Facilities” Services Marketing Quarterly, 37(1), pp. 2435.

Gunelius, S. (2010, July 3), “The shift from cONsumers to PROsumers”, Forbes, Retrieved from http://www.forbes.com/sites/work-in-progress/2010/07/03/the-shift-fromconsumers-to-prosumers/.

Harrison-Walker, L. J. (2001), “The measurement of word-of-mouth communication and an investigation of service quality and customer commitment as potential antecedents”, Journal of Service Research, 4(1), pp. 60-75.

Hennig-Thurau, T., Gwinner, K. P., Walsh, G., and Gremler, D. D. (2004), “Electronic word-of-mouth via consumer-opinion platforms: What motivates consumers to articulate themselves on the Internet?”, Journal of Interactive Marketing, 18(1), pp. 38-52. 
doi:10.1002/dir.10073.

Herr, P. M., Kardes, F. R., and Kim, J. (1991). Effects of word-of-mouth and productattribute information on persuasion: An accessibility-diagnosticity perspective. Journal of consumer research, 17(4), pp. 454-462.

Jeong, E., and Jang, S. S. (2011), “Restaurant experiences triggering positive electronic word-of-mouth (eWOM) motivations”, International Journal of Hospitality Management, 30 (2), pp. 356-366.

King, R. A., Racherla, P., and Bush, V. D. (2014) “What We Know and Don't Know About Online Word-of-Mouth: A Review and Synthesis of the Literature”, Journal of Interactive Marketing 28 (2014) 167-183.

Korgaonkar, P. K. and L. D. Wolin (1999), “A Multivariate Analysis Of Web Usage,” Journal of Advertising Research, 39 (2), pp. 53-68.

Laughlin, J. D. and J. B. MacDonald (2010), “Identifying Market Mavens Online By Their Social Behaviors In Community Generated Media,” Academy of Marketing Studies Journal, 14 (1), pp. 55-70.

Loureiro, S. M. C., and Kastenholz, E. (2011), “Corporate reputation, satisfaction, delight, and loyalty towards rural lodging units in Portugal”, International Journal of Hospitality Management, 30(3), pp. 575-583.

Memarzadeh, F., Blum, S. C., and Adams, C. (2015), “The impact of positive and negative e-comments on business travelers' intention to purchase a hotel room”, Journal of Hospitality and Tourism Technology, 6(3), 258-270.

Neilsen (2013), “Under the Influence: Consumer Trust in Advertising”, from http://www.nielsen.com/us/en/insights/news/2013/under-the-influence-consumer-trust-in- 
advertising.html.

Parasuraman, A., and Zeithhaml, V. (1988), "SERVQUAL: A multiple item scale for measuring consumer perceptions of service quality”, Journal of Retailing, 64, pp. 12-40.

Perkins, B. (2009), “The Power of Viral Revenge,” Computerworld, July 20 - July 27, 40.

Pietro, L. D., Virgilio, F. D., and Pantano, E. (2012), “Social network for the choice of tourist destination: Attitude and behavioural intention”, Journal of Hospitality and Tourism Technology, 3(1), 60-76.

Rensink, J. M. (2013), “What motivates people to write online reviews and which role does personality play? A study providing insights in the influence of seven motivations on the involvement to write positive and negative online reviews and how five personality traits play a role”, University of Twente, Dissertation.

Sánchez-García, I., and Currás-Pérez, R. (2011), "Effects of dissatisfaction in tourist services: The role of anger and regret”, Tourism Management, 32(6), pp. 1397-1406.

Siuda, P., and Troszynski, M. (2016), "Natives and tourists of prosumer capitalism: On the varied pro-prosumer activities of producers exemplified in the Polish pop culture industry”, International Journal of Cultural Studies, In Press. 1367877916666117.

Söderlund, M. (1998), “Customer satisfaction and its consequences on customer behaviour revisited: The impact of different levels of satisfaction on word-of-mouth, feedback to the supplier and loyalty”, International Journal of Service Industry Management, 9 (2), pp. 169188.

Sun, L.B. and Qu, H. (2011), "Is there any gender effect on the relationship between service quality and word-of-mouth?”, Journal of Travel and Tourism Marketing, 28(2) pp. 210- 
224.

Swanson, S. R. and Hsu, M. K.. (2009): Critical incidents in tourism: failure, recovery, customer switching, and word-of-mouth behaviors. Journal of Travel \& Tourism Marketing: 26:2, p. 180-194.

Yen, C. L. A., \& Tang, C. H. H. (2015), "Hotel attribute performance, eWOM motivations, and media choice”, International Journal of Hospitality Management, 46, pp. 7988.

Yoo, C. W., Sanders, L. G., and Moon, J. (2013). Exploring the effect of e-wOM participation on e-loyalty in e-commerce. Decision Support Systems, 55(3), pp. 669-678. doi:10.1016/j.dss.2013.02.001

Yoo, K., and Gretzel, U. (2008). What motivates consumers to write online travel reviews. Information Technology and Tourism, 10, pp. 283-295.

Zeithaml, V. A., Berry, L. L., and Parasuraman, A. (1996). The behavioral consequences of service quality. the Journal of Marketing, pp. 31-46.

\section{Biographical Details}

Dr. Monica B. Fine is an Assistant Professor of Marketing at Coastal Carolina University. Research authored by Dr. Fine has been published in a wide variety of outlets including: Journal of Brand Management, Services Marketing Quarterly, Journal of Digital and Social Media Marketing, Tourism, Culture \& Communication, Southern Business Economic Journal, and Operations Management Education Review. Monica also owns a consulting business called B. Fine Consulting.

Dr. John T. Gironda is an Assistant Professor of Marketing at Nova Southeastern University. He 
received his Ph.D. from Florida Atlantic University. His teaching and research interests include Digital Marketing and Advertising, Branding, Consumer Behavior, and Services Marketing. His research has been published in the Journal of Marketing Management, Journal of Retailing and Consumer Services, European Journal of International Management, and Journal of Internet Commerce. He has also presented papers at a number of academic conferences including: American Marketing Association Summer and Winter Educator's Conferences, Academy of Marketing Science Annual Conference, Society for Marketing Advances Annual Conference, and Academy of Marketing Science World Marketing Congress.

Dr. Maria Petrescu is an Assistant Professor of Marketing at Nova Southeastern University, Huizenga College of Business and Entrepreneurship. Her main research areas include digital marketing, social media, international marketing and entrepreneurship. Dr. Petrescu has published in journals such as the Journal of Product and Brand Management, the Journal of Promotion Management, the Journal of Retailing and Consumer Services, the Journal of Marketing Analytics and the Journal of Internet Commerce, on topics such as online price dispersion, viral advertising and mobile marketing. She also participated in prestigious conferences, such as the American Marketing Association Summer Educators’ Conference, the Academy of Marketing Science Conference, the AMS World Marketing Congress and the Society for Marketing Advances Conference. 


\section{Tables}

Table 1

\section{Panel 1: Descriptives}

\begin{tabular}{lcrrrrr} 
& N & Range & Minimum & Maximum & Mean & Std. Deviation \\
\hline Review Behavior & 204.0 & 6.0 & 1.0 & 7.0 & 3.828 & 1.8984 \\
Intrinsic Motivators & 204.0 & 6.0 & 1.0 & 7.0 & 5.560 & 1.4325 \\
Extrinsic Motivators & 204.0 & 6.0 & 1.0 & 7.0 & 3.768 & 1.6321 \\
Tangibles & 204.0 & 5.0 & 2.0 & 7.0 & 5.567 & .9849 \\
Reliability & 204.0 & 5.0 & 2.0 & 7.0 & 5.389 & 1.2591 \\
Responsiveness & 204.0 & 6.0 & 1.0 & 7.0 & 4.369 & 1.7108 \\
Assurance & 204.0 & 6.0 & 1.0 & 7.0 & 5.089 & 1.2929 \\
Empathy & 204.0 & 6.0 & 1.0 & 7.0 & 4.726 & 1.5917 \\
Intrinsic Motivators & 204.0 & 6.0 & 1.0 & 7.0 & 5.560 & 1.4325 \\
Extrinsic Motivators & 204.0 & 6.0 & 1.0 & 7.0 & 3.768 & 1.6321 \\
Age: & 204.0 & 7.0 & 1.0 & 8.0 & 3.662 & 1.6017
\end{tabular}

\section{Panel 2: Correlation Matrix}

\begin{tabular}{|c|c|c|c|c|c|c|c|c|c|}
\hline & 1.00 & 2.00 & 3.00 & 4.00 & 5.00 & 6.00 & 7.00 & 8.00 & 9.00 \\
\hline 1. Tangibles & 1.00 & & & & & & & & \\
\hline 2. Reliability & $.558^{* *}$ & 1.00 & & & & & & & \\
\hline $\begin{array}{l}3 . \\
\text { Responsiveness }\end{array}$ & $.264^{\star *}$ & $.236^{\star *}$ & 1.00 & & & & & & \\
\hline 4. Assurance & $.358^{\star *}$ & $.365^{\star *}$ & 0.02 & 1.00 & & & & & \\
\hline 5. Empathy & $.218^{\star \star}$ & $.207^{\star \star}$ & $.505^{\star *}$ & $.257^{\star \star}$ & 1.00 & & & & \\
\hline 6. Intrinsic & 0.16 & $.215^{* *}$ & 0.01 & 0.14 & 0.02 & 1.00 & & & \\
\hline 7. Extrinsic & 0.06 & 0.01 & -0.15 & 0.09 & $-.184^{*}$ & $.244^{\star *}$ & 1.00 & & \\
\hline $\begin{array}{l}\text { 8. Review } \\
\text { Behavior }\end{array}$ & 0.07 & 0.12 & -0.02 & 0.11 & -0.07 & $.478^{* *}$ & $.395^{\star *}$ & 1.00 & \\
\hline 9. Age & 0.08 & 0.01 & -0.03 & -0.07 & -0.14 & -0.14 & 0.00 & -0.10 & 1.00 \\
\hline
\end{tabular}

**. Correlation is significant at the 0.01 level (2-tailed).

*. Correlation is significant at the 0.05 level (2-tailed). 
Table 2: Exploratory factor analysis

SERVQUAL

Tangibles

Hotels you've stayed in have up to date equipment.

Hotels you've stayed in have visually appealing physical

facilities.

\section{Reliability}

When hotels you've stayed in promise to do something at a certain time they do so.

sympathetic andreassuring.

\section{Responsiveness}

Hotels you've stayed in do not tell you when services will be performed.

respond to customer requests promptly.

\section{Assurance}

employees.

Employees of hotels you've stayed in get adequate support from hotels to do their jobs well.

\section{Empathy}

Employees of hotels you've stayed in do not know what your needs are.

individual attention.

\section{Loadings Eigenvalue}

\section{Cronbach}

alpha

\section{Intrinsic motivators}

experiences.

right product.

I can express my joy about a good buy. 
I can tell others about a great experience.

$.873 \quad .118$

I am so satisfied with a company and my

experience that I want to help the company be

$.806 \quad .116$

successful.

In my own opinion, good companies should be supported.

$.836 \quad .125$

\section{Extrinsic motivators}

I expect to receive tips or support from other users
I believe the platform operator knows the person

message.

I believe companies are accommodating when I publicize the matter.

The platform operator will stand up for me when speaking to the company.

\section{Cronbach}

Loadings Eigenvalue alpha

\section{Review behavior}

I always share my experiences with other

members online.

I always share my opinions with other

members online.

I post links of videos online.

I post links of pictures online.

I post links of articles online. 
Table 3: Multivariate regression results for Review behavior

\begin{tabular}{lccccc} 
& $\mathbf{B}$ & $\mathrm{SE}$ & Beta & \multicolumn{1}{c}{ t } & Sig. \\
\hline $\begin{array}{l}\text { Intrinsic } \\
\text { Motivators }\end{array}$ & $\mathbf{0 . 4 7 0}$ & $\mathbf{0 . 0 7 5}$ & $\mathbf{0 . 4 6 1}$ & $\mathbf{6 . 2 9 0}$ & $\mathbf{0 . 0 0 1}$ \\
$\begin{array}{l}\text { Extrinsic } \\
\text { Motivators }\end{array}$ & $\mathbf{0 . 3 0 7}$ & $\mathbf{0 . 0 7 5}$ & $\mathbf{0 . 3 0 8}$ & $\mathbf{4 . 1 1 3}$ & $\mathbf{0 . 0 0 1}$ \\
Tangibles & $\mathbf{- 0 . 2 1 3}$ & $\mathbf{0 . 0 9 3}$ & $\mathbf{- 0 . 2 0 6}$ & -2.295 & $\mathbf{0 . 0 2 3}$ \\
Reliability & $\mathbf{0 . 1 9 6}$ & $\mathbf{0 . 0 8 7}$ & $\mathbf{0 . 1 9 4}$ & $\mathbf{2 . 2 5 6}$ & $\mathbf{0 . 0 2 6}$ \\
Responsiveness & 0.112 & 0.101 & 0.113 & 1.102 & 0.272 \\
Assurance & -0.057 & 0.082 & -0.055 & -0.691 & 0.491 \\
Empathy & -0.127 & 0.101 & -0.128 & -1.260 & 0.210 \\
Age & $\mathbf{- 0 . 1 4 6}$ & $\mathbf{0 . 0 4 4}$ & $\mathbf{- 0 . 2 3 1}$ & $-\mathbf{3 . 3 2 1}$ & $\mathbf{0 . 0 0 1}$ \\
\hline
\end{tabular}

Adjusted R-square $=0.373 ; F=10.95 ; p<0.001$

Table 4: ANOVA results

$\begin{array}{ccccccc} & \begin{array}{c}\text { Type } \\ \text { III Sum } \\ \text { of } \\ \text { Squares }\end{array} & \text { df } & & \begin{array}{c}\text { Mean } \\ \text { Square }\end{array} & \text { F } & \text { Sig. } \\ \text { - Preferred } & \text { 25.945 } & 4 & 6.486 & 7.333 & 0.001 \\ \text { platform } & 25.94\end{array}$

Facebook

Google

TripAdvisor

Yelp

$\mathbf{a} / \mathbf{b}$

Mean

Mean

Mean

Mean difference Sig. difference Sig. difference Sig. difference (a-b) (a-b) (a-b) (a-b)

\section{Facebook}

Google

$-0.250$

0.429

Tripadvisor

$-0.375$

0.101

$-0.125$

0.638

Yelp

$-0.470$

0.192

$-0.220$

0.567

$-0.095$

0.763

None

$-1.020$

0.001

$-0.771$

0.004

$-0.646$

0.001

$-0.550$

0.850 
Table 5: Hypotheses and Results

\begin{tabular}{|l|l|l|}
\hline & \multicolumn{1}{|c|}{ Research Hypotheses } & \multicolumn{1}{|c|}{ Result } \\
\hline H1 & $\begin{array}{l}\text { Intrinsic motivators have a positive relationship with online } \\
\text { eWOM review behavior engagement. }\end{array}$ & Supported \\
\hline H2 & $\begin{array}{l}\text { Extrinsic motivators have a positive relationship with online } \\
\text { eWOM review behavior engagement. }\end{array}$ & Supported \\
\hline H3 & $\begin{array}{l}\text { The level of service reliability has a positive relationship with } \\
\text { online eWOM review behavior engagement. }\end{array}$ & Not Supported \\
\hline H4 & $\begin{array}{l}\text { The level of service reliability has a positive relationship with } \\
\text { online eWOM review behavior engagement. }\end{array}$ & Supported \\
\hline H5 & $\begin{array}{l}\text { The level of service responsiveness has a positive } \\
\text { relationship with online eWOM review behavior } \\
\text { engagement. }\end{array}$ & Not Supported \\
\hline H6 & $\begin{array}{l}\text { The level of service assurance has a positive relationship with } \\
\text { online eWOM review behavior engagement. }\end{array}$ & Not Supported \\
\hline H7 & $\begin{array}{l}\text { The level ofservice empathy has a negative relationship with } \\
\text { online eWOM review behavior engagement. }\end{array}$ & Not Supported \\
\hline H8 & $\begin{array}{l}\text { There are differences in online eWOM review behavior as a } \\
\text { function of the review platform preferred. }\end{array}$ & Partially Supported \\
\hline H9 & $\begin{array}{l}\text { Age has a negative relationship with online eWOM review } \\
\text { behavior engagement. }\end{array}$ & Supported \\
\hline
\end{tabular}

